\title{
Thematization and Ideological Representations in Murder Stories in the Kenyan Dailies
}

Elizabeth Nafula Khaemba*

PhD Student; Moi University Kenya

DOI: $10.36348 /$ sijll.2020.v03i05.001

| Received: 16.04.2020 | Accepted: 23.04.2020 | Published: 09.05.2020

*Corresponding author: Elizabeth Nafula Khaemba

Abstract

Any form of language use is imbued with a particular meaning, purpose and ideological representation. As such, the order of Theme and Rheme and their organization in the clause as a message is not arbitrary or value free; it can be manipulated along with units of information, given and new, to achieve a rhetorical purpose and reflect a specific angle of telling a story (Halliday 2004). On the basis of the purposively sampled news stories on murders in Kenya from the year 2018 to 2019, the study qualitatively examines the efficacy of the Systemic Functional Grammar (SFG), as a theoretical tool in the analysis of ideology in four different newspaper in Kenya i.e the Daily Nation, the Standard, the Star and the Nairobian, in relation to the representation of murder stories. This study examines thematization in these newspapers. It hypothesizes that external forces have altered the main purpose of the media through the way news is written and organized; and that from a socio-linguistic point of view, the consequences of these forces are revealed within the textual features of texts. The findings indicate that that the order of theme and Rheme and their organization in the clause as a message are neither arbitrary nor value free. They can be manipulated along with the units of information to achieve a rhetorical purpose and reflect a specific angle of telling a story.

Keywords: Thematization, Ideology, Representation.

Copyright @ 2020: This is an open-access article distributed under the terms of the Creative Commons Attribution license which permits unrestricted use, distribution, and reproduction in any medium for non-commercial use (NonCommercial, or CC-BY-NC) provided the original author and source are credited.

\section{INTRODUCTION TO THE STUDY}

Media has, since time immemorial, been used to report about events happening in the societies and the world at large. They are the dominating presenters of language in our society. News language has a mass audience, it's the few talking to the many, and thus has enormous power and influence in the world. Through language use in their reportage of news, people's perspectives, opinions and views about these situations are shaped. The Media therefore intentionally uses textual (i.e., words, phrases, statements), visual (i.e images photographs, graphics) language or both to represent attitudes, entities, individuals, ideals and institutions. It is from these representations that they position and differentiate themselves from each other. These sentiments are well shared by Anctil 2008 who asserts that, "The image people have of an institution influences so many of the decisions they will make and the actions they will take as a result of that image" (p. 33)

\section{LANGUAGE AND IDEOLOGY}

Many studies (Fairclough [1]) carried out on language in relation to media and ideologies have shown that social, political and economic factors have an effect on how the world is represented in the media and that anything that is said or written about the world is articulated from a particular ideological position and as such, language is not a clear reflection of the world reality but its refraction, Fowler [2].

Fairclough introduces the concept of ideological struggle, which takes place in and over language. He asserts that at the centre of this struggle lies the power to decide things such as which word meanings are "appropriate" or "correct" (pp. 88-89). This means therefore that the way events are represented on the basis of the elements of linguistic structure is key in news report. Fowler asserts that ideology is already imprinted in the available discourse and that news reporters do not select events to be reported and then consciously wrap them in value-laden language which the reader passively absorbs, language values which are ideological are already in the language, independent of both the news reporter and the reader. Fowler further on notes that news does not merely reflect reality but actively constructs it. Fairclough [3]supports this view by stating that the ideological nature of media language entails specific 
constructions of the world and of social identities and relations. Fowler [4] regards language as a social practice which endeavours to maintain social and institutional relations through the continuous propagation of ideology. According to Fowler [2], values and ideology differ, for instance, in the different choices of words that are found in newspapers. However, it is not only vocabulary that may be ideologically invested. Any feature of linguistic structure can be ideologically significant, whether it be grammar, syntax, semantics, etc. It is upon this observation that this study sets to find out how different ideologies are hidden in murder news by reporters via Thematization analysis.

\section{LITERATURE REVIEW}

Many scholars in Linguistics (Thompson, White \& Kitley [5], have carried out studies on the language of news report in general and news report about murder and crime-related events in particular Lombardi, D [6] Abuga J,A [7], which have taken several angles in Linguistics ranging from the structures of the news report, language used in reporting and many other issues. Some have explored the rhetorical properties of the modern newspaper report so as to account for the distinctive style of news report (e.g Aini, N and Widodo, P [8]; Abuga J,A; Ononye, [9]; Hudock, L while others have tried to explore the relationship that exists between the ideological positions of the media and language use (e.g Ononye [9]; Lombardi, D [6] Timucin, [10]. Studies conducted by Ononye and Timucin, $\mathrm{M}$ are worth noting. The former focused on lexico-stylisitc choices and media ideology in newspaper reports on Niger Delta (DN thereafter) conflicts. It tries to explore the relationship that exists between the ideological positions of the media and the linguistic choices made in their reports of the ND conflicts. It concluded that both the paradigmatic and syntagmatic features have largely been used to achieve three ideological ends which included: Picking out and framing participants as perpetrators of the violence in the discourse, Evaluating specific entities and their roles in the conflict and Reducing the impact of the activities of the news actors. Ononye's study greatly informs the article at hand in terms of the ideological aspects advanced by the media in reporting. This study is prompted by the fact that many studies on the media had focused so much on pragmatic, sociolinguistic, critical linguistics perspectives and lexico-stylistic approach rather than on thematic concerns. The novelty of the article in hand is that it is studying a new area of research. Thematization analysis of the language used in the newspaper headlines and introductory paragraphs depicting murders will benefit the readers of the newspapers.

\section{THEORETICAL FRAMEWORK}

\section{Systemic Functional Linguistics}

As a linguistic theory, Halliday's Systemic Functional Linguistics (henceforth SFL) is based on the main assertion that language is a (social) semiotic system and that its users have unlimited choice in the creation of meanings. Systemic linguists, just like critical discourse analysts, share a common interest in language as a social semiotic. They claim that the function of language use is to create meanings that are informed by the cultural and social context of their exchange; therefore language use is a semiotic process. The functional aspects of the systemic approach are concerned with how language is used by people and how language is structured for use, whereas the semantic aspect questions the types of meanings made with the use of language and how language is used to make such meanings. Halliday [11] observes that there are three main kinds of meanings, known as metafunctions, used simultaneously in the structure of language: ideational, interpersonal, and textual. The functions of a clause are integrated in three systems of choices that correspond to these meanings: Transitivity, Mood, and Theme.

Since the central concern of this study is on textual meaning achieved through thematization, the following section looks at textual metafunction in some details. Textual meaning is primarily realized by thematic structure, which in turn consists of the Theme, i.e. the beginning of the clause, and the Rheme, i.e. the rest of the clause. The Theme includes the first ideational participant as well as anything that may precede this, and its function is that of locating and orienting the clause within its context (Halliday \& Matthiessen [12]). This means that the way we start a clause helps us integrate it into the general context of our discourse while at the same time determining the way in which the new information provided by the clause will then unfold. As such; Theme and Rheme are two important elements of the textual metafunction which the article in hand is interested in. The adoption of SFG enables this study to effectively use thematization to explore underlying social and ideological representations with regard to the way print media represents murder stories in the newspapers. Thematization is defined as a transformational process by which some parts of the clause, such as a complement or an Adjunct, are placed at the initial position which relates to Halliday's Model of ThemeRheme and the selection of these elements in the clause.

\section{METHODOLOGY}

The approach taken in the analysis is descriptive in nature. Specifically, the study purposefully sampled a total of 23 samples of both headlines and introductory paragraphs from four newspapers in Kenya: the Daily Nation, the Standard, the Star and the Nairobian covering different murders that occurred across the country in the years 2018 and 2019. Since different media houses were covering the events, the news consumers were actively searching for information about those coverages and naturally, different media groups being aware of this, would alter, 
edit and update content accordingly. Through these efforts, different representations of the murder events emerged on the basis of thematization choices as exampled below. In all the examples presented, thematic elements are underlined and rhematic ones, which form new information, are presented in bold phase:

\section{DN Article 1 (2018)}

\section{Obado's PA still in custody as police intensifies watch over all.}

The theme and the subject in the above example are 'conflated' (Thompson 2004:144) and as such, Obado's PA is both the theme and the subject of the sentence. The information focus of the report is conveyed by the rheme still in custody as police intensify watch over all which modifies the theme Obado's PA. Through avoiding using the name of Obado's PA, Michael Oyamo and instead use possessive form helps to project a negative representation of Obado by depicting him as the main culprit in the murder event through placing him at the centre of discourse. The DN is about Obado's PA who is still in custody. The information sequence in this report is thus unmarked and the theme has a relatively impersonal tone.

\section{STD Article 2 (2018)}

Man at the epicenter of murder mystery, Michael Oyamo, the man holding the trump card in the killing of Sharon Otieno is a quiet man with intimidating physique.

The writer chooses to pre- and post-modify the topical theme Michael Oyamo with adjectival phrases man at the epicenter of murder mystery and the man holding the trump card in the killing of Sharon Otieno to infer to the role this man played in the murder event, provide the readers with the background information of the person in the text, lay foundation for introducing him to the readers and arouse the readers' curiosity to know more about him. The theme of the news report is thus presented with a subject which is a nominal group complex with three nominal groups; one having the noun man heavily post modified with complex prepositional phrases, the middle one being simple proper noun Michael Oyamo and the last one having the noun the man post modified with an identifying participle phrase holding the trump card in the killing of Sharon Otieno. Through the heavy modification, the author wishes to identify Michael Oyamo as the main culprit in the murder event; information relayed at the thematic position.

The thematic element is modified by the rhematic element is a quiet man with intimidating physique. Through contrasting Oyamo's character trait as quiet with intimidating physique, the author presents a very subjective point of view about the subject which aims both at framing Oyamo as culpable and reconfirming the information at the thematic element that indeed he is at the epicenter of the murder mystery. It thus leaves a first negative impression of Oyamo, since it incriminates Oyamo and makes readers believe that he is a culprit of Sharon's murder.

The STD reporter thus focuses on Michael Oyamo and his role in the murder by placing this information at the beginning of the clause. The information focus conveyed by the rhematic element effectively modifies the thematic information. His intimidating physique and thus aggressive nature effectively places him at a culpable position and renders him a culprit of the murder committed; a frame or view that is in line with the concerned media house ideology.

1. DN Article 3 (2018)

Investigations boss says arrests of key suspect to be made soon.

2. DN Article 4 (2018). Police say probe will not spare any one and arrests will be made soon.

3. $\quad$ STD Article 5 (2018) student Police question 12 in murder of varsity

The above news headlines are presented as unmarked structures. This follows the Hallidayan definition of theme and his categorization of markedness which dictates that English language being an SVO/C language, structures exhibiting such an order are considered unmarked. The term police is repeatedly presented as given or predicted information in the thematic position. It is sometimes replaced by investigation's boss which has same semantic value as police. Repetition of these lexical items as given information indicates a process of authenticating the story. New information in all the texts effectively modifies the given information by trying to show that the arrests and questioning are done by the police. Through the theme and information structure, the writer is able to construe the investigative unit positively, as a unit set out to bring the murder culprits to books.

\section{4. $\quad$ DN Article 6 (2018)}

Stab wound through mother's abdomen dealt lethal blow to seven month old.

8 number of stab wounds on Sharon's body, according to pathologists.

The topical theme stab wound is modified in both news items. In the $1^{\text {st }}$ text, it is post-modified by the prepositional phrase through mother's abdomen while in the $2^{\text {nd }}$ text it is pre-modified by 8 number of and post-modified by on Sharon's body. Though this modification coupled with the repetition of the topical theme stab wound at the thematic position in both news items, the author is able to reveal the cruel nature of the murderer and thus persuade the readers to condemn the 
act. Repetition of the topical theme aims to project a negative representation of the perpetrators through incriminating them; an ideology that could be consistent with the media house stance.

\section{DN Article 7 (2018)}

Mother had 8 stab wounds on neck and back, but fatal blow to the baby was through abdomen.

The above clause demonstrates the use of marked information structure in the sense that both the thematic and rhematic elements convey given information which has already been mentioned in the previous report. The association between mother and the stab wound/s is repeated now three times to emphasize on the cruel nature of the murder event and in the long run persuade the readers to believe that the perpetrator is liable to a heavy punishment.

In the subordinate clause, the writer uses but, fatal blow to the baby as a theme and was through abdomen as the rheme. The coordinating conjunction but which is normally used to mark contrast of ideas has been used here to draw the reader's attention from the injuries inflicted on the mother in the first clause which according to the writer were nothing compared to the deadly one inflicted on the baby. In doing so, the writer successfully associates the perpetrator to two separate counts of crimes. One is the murder of a mother and the second one is the murder of her unborn baby. In doing so the author effectively advances a case against the perpetrator. The textual theme but premodifying the topical theme fatal blow in the $2^{\text {nd }}$ clause thus serves to magnify the murder event. It is therefore both an emphatic and a persuasive device ideologically used by the author and the media house concerned to incriminate the perpetrator. The effect of using the device can be compared to the use of the English coordinating conjunction not only... but also. Its usage therefore brings out the killer's cruelty which is likely to prompt the readers into inferring to the innocence of the murdered student. This effect is further supported by the author's repetition of the lexical item stab wound and this time round treating it as new information by placing it at the rhematic position yet it is given information. Through repetition and putting it as rhematic element, the author wishes to emphasize the injustice meted on the dead and negatively describe the killer's actions.

\section{DN Article 8 (2018)}

Obado puts on a strong show after day long date with police.

Is he under arrest or just enjoys better security? police cagey on governors status.

7. DN Article 9 (2018)

Obado owns up to share affair

$\underline{\text { Obado }}$ brings out family, denies role in

\section{Sharon's murder.}

Governor appears at the news conference proclaims innocence and calls for speedy probe into Rongo University student's killings.

8. STD Article 10 (2018)

Governor denies any link to the murder of student, says he planned to support her.

9. DN Article 11 (2018)

Governor confesses that he was even when he trots out his family wife and children in an attempt to shore up his family credentials.

10. DN Article 12 (2018)

Governor struggles to show that there was no animosity between him and his girlfriend.

The unmarked syntactic order for reporting news in English is subject-predicator-complement which is exhibited in the above news items apart from the second clause of article 8 which starts with an interrogative sentence. The thematic element Obado which is presented as given information is repeated severally in the news reports and replaced by Governor in some news items. Analysis of the rhematic elements in many of the reports above indicates an emphasis on the governor's struggle to clear his name which is likely to prompt the reader into accepting the governor's innocence. This argument is supported by the author's choice of words at the rhematic position such as owns up, proclaims, confesses, denies, calls for which delinks him from the crimes leveled against him.

The use of unmarked thematic structure coupled with emphasis, through repetition of certain lexical terms and choices of words which delink the governor from the crime, at the rhematic position indicate a process of persuasion to construe Obado positively. Obado's innocence is thus constantly repeated as new information through a persuasion process to construe him as a victim of allegations rather than a culprit of murder. In a different murder, the reporter in 13 uses appositives:

\section{DN Article 13 (2018) \\ Another girl, another murder}

The unmarked syntactic order for reporting news in English is subject-predicator-complement. In the news headline above however, DN reporter uses appositives; a strategy adopted to attract the readers' attention to the main topic of event. Given Halliday's definition of theme and his categorization of markedness, this study considers the above news headline as marked both thematically and also in terms of information structure. Another girl is new information, not yet reported previously, but it occupies the position of the given information and another murder is new information. The modification of the nouns girl and murder by another, the repetition of the 
sentence structure and the lexical item another and the use of marked informational structure indicate a process of persuasion to construe the fact that killing has become a normal activity which happens surprisingly frequently within short intervals. The author is thus calling upon the government to do something to that effect.

\section{The Star Article 14 (2018)}

Witness: Kamangara's killing depicted as a slaying stemming from a love triangle.

The Star report focuses on Kamangara and her killing by placing them at the initial position of the clause. By thematizing the nominalized expression, Kamangara's killing readers' minds are triggered by questions surrounding the killing e.g why the killing, who killed and why? Through nominalization, the actor of the action is backgrounded through omission. On the other hand, the rhematic element depicted as slaying stemming from a love triangle effectively modifies the theme of clause since it consists of elements that, at a glance, try to answer the questions implicitly raised up at the thematic position.

\section{The Star Article 15 (2018)}

Reavealed: Frantic bid to dump wife's body. Kori's wife, Mary was allegedly murdered.

The star reporter focuses on Kori and his wife who is Mary, by placing them at the initial position of the second clause. The thematic elements provide given information simply because the same information appears in the previous report in the rhematic position. By foregrounding it, the reporter wishes to give more prominence to the marital status of Mary than to the fact that she was murdered. Through alluding to the relationship of husband and wife between the killer and the killed, the reporter brings forth an emotional tone making the readers sympathize with the deceased.

\section{The Star Article 16 (2019)}

Fresh details emerge in Jowie murder case

This report was published on $22^{\text {nd }}$ June 2019 and the murder of Monica Kimani took place in 2018. Since her killing, the investigative unit's progress has been the subject of many reports. Taking the context of situation into account, Jowie's murder case is thus given information yet the reporter chooses to present it as new information by placing it at the rhematic position consequently; Fresh details refers to unknown information yet the reporter chooses to present it as given information by placing it at the thematic element thereby creating some sort of an interchange of information structure. In this case, it can be argued that the writer wishes to remind the readers of the long forgotten murder case involving Jowie. The premodification of the thematic element details with the word fresh reveals that new and different evidence in connection to the said case has been found. This language use can thus be said to be implying on the thorough nature of the investigative unit.

\section{The Star Article 17 (2018) \\ Witness: Monica's blood found on Jowie's \\ shorts}

The news producers of the above report choose to present Monica's blood as given information by placing it at the initial position of the clause and found on Jowie's shorts as new information. The choice of theme and rheme and their interplay with given and new information suggests Jowie's connection to Monica's killing. This connection is triggered by a rationalization process which enables the readers to logically perceive Jowie as a perpetrator of the crime committed.

\section{Nairobian Article 18 (2018)}

Dead end: Moneyed, possessive lover was 30 years older and ready to die than loose her to young men.

By placing the words dead end initially at the global level of the discourse ie. as a report summary, the reporter wishes to inform readers of the desperate situation of the killed since the lexeme dead end means a point where no further progress is possible. At the local level, the placement of moneyed, possessive lover at the thematic position of the clause aims at showing the negative traits of the lover as the rhematic elements was 30 years older and ready to die... effectively expounds on why the lover was possessive and why the author chooses to use the lexeme dead end at the thematic position.

\section{Nairobian Article 19 (2018)}

Slayed queen: murdered beauty within a short time bought property worth millions, planned to wed Sudanese boyfriend.

18. Nairobian Article 20 (2018)

Within a very short span, Monica Kimani had bought houses in Ruaka, Imara Daima and parcels of land in the outskirts of the city.

By choosing to pre-modify the thematized head of the nominal group Monica Kimani puts within a very short span in a thematic position so as to mark time in article 21. Such positions are usually reserved for given or known information Fries 1994:231. This is indeed true since both theme and rheme in example 21 above convey given information by virtue of the fact that this clause carries information that is almost similar to the one in 20. Also, the use of past tense bought and the perfect aspect had shows that the information conveyed is given. Through choosing a marked information structure, the reporter wishes to present the information as very crucial and such, should not be taken for granted. As noted in Hawthorn 1987 and Van 
Dijk 1998 persuasive techniques include emphasis, direct repetition, modification, association and interpretation of statements. As such, the reporter of the above report finds it necessary to repeat the information 20 in 21 to win the readers' consent about the information being reported and shape their opinions. Through the use of marked thematic structure, presentation of given information as new and given, the use of repetition and pre-modification of information, the reporters of the above report aim to show the aggressive nature of Monica Kimani.

\section{DN Article 21 (2018)}

A sh. 14,000/= birthday gift to Ivy Wangechi could have been the last straw that drove Naftali Njahi Kinuthia to butcher her with an axe.

The report focuses on a shs.14, 000/= birthday gift and Ms Ivy Wangechi who is the beneficiary of the gift. The placement of this information at the beginning of the clause is intended to convince the readers about the good intentions Naftali had for Ivy. This information is presented as a known fact by virtue of its position i.e thematic position. Right from the beginning of the report, readers are encouraged to infer to the generosity of Naftali and interpret any references made about him in any other news report on the basis of his caring nature and his effort to support his girlfriend. Through this language use, Naftali is represented favorably.

\section{0. $\quad$ STD Article 22 (2019) \\ Murder suspect sent victim cash for birthday, police say. \\ 21. $\quad$ STD Article 23 (2019) \\ Police boss says man traveled to Eldoret last Friday after student ignored his calls after he sent her money.}

The clause 23 construes the use of yet another marked information structure since it carries information which is mentioned before in the previous clause 22. Police boss occupies a thematic position hence presents given information. The rhematic position is occupied by says man traveled to Eldoret... which is presented as new information yet it is known information by virtue of the fact that it has been reported in 22. Though this marked information structure, the writer effectively creates and an association between money sent by the murder suspect and the death of the student; an association that enables the writer to persuade the readers into believing that the money sent, and by extension the student herself, was the initiating agent of the problem. If that money hadn't been sent, then there would have been no reason for the man to travel to Eldoret.

\section{Findings from the analysis of the data}

The study finds out that marked structures are not unusual in news texts, although the general tendency is to use the unmarked ones. In fact, in some contexts the marked structures may even be the more natural choice. This therefore means that the order of theme and Rheme and their organization in the clause as a message are neither arbitrary nor value free. They have been manipulated along with the units of information i.e given and new, to reflect the following ideological stances:

- Framing victims innocently or as initiators of the murder events in the discourse.

- Framing perpetrators innocently and supporting the fact that they have no case to answer or as culpable and thus liable for punishment.

- Choosing such hedging devices that can be interpreted as either a display of the writers' noncommittal nature to the report or covert support of a perpetrator's innocence.

- Putting the readers into a social group of the vulnerable group which seeks for protection and justice over the killing, from the government.

- Construing the investigative unit positively, as a unit set out to bring the murder culprits to book.

In relating the ideologies to specific newspapers, these different ideological moves were invariably employed in the murder discourses sampled. No specific ideology was associated with a particular newspaper.

\section{CONCLUSION}

Naturally, no far-reaching conclusions can be drawn on the basis of a sample of the 23 articles. The aforementioned observations about the nature of subjectivity found concern only the news murder stories analyzed and as such, they cannot be generalized to apply to the representation of events in other news genres like commentaries, letters to the editors, political discourse etc in the said newspapers or other newspapers not handled in this study.

\section{REFERENCES}

1. Fairclough, N. (1989). Language and power. London: Longman.

2. Fowler, R. (1991). Language in the news: Discourse and ideology in the press. London: Routledge.

3. Fairclough, N. (1995a). Media discourse. Cambridge: Polity Press.

4. Fowler, R. (1986). Linguistic Criticism. Oxford: Oxford University Press.

5. Thomson, E. A., White, P. R. R., \& Kitley, P. (2008). 'Objectivity' and 'hard news' reporting across cultures: Comparing the news report in English, French, Japanese and Indonesian journalism'. Journalism Studies, 9(2), 212 - 228. 
6. Lombardi, D. (2018). Critical Discourse Analysis of Online News Headlines: A Case of the Stoneman Douglas High School Shooting. Malmo University:Published Master Thesis

7. Adhoch, J. (2016). A Critical Examination of Media Representation of Terrorism in Kenya. University of Nairobi: Published M.A Thesis

8. Aini, N., \& Widodo, P. (2018). Critical Discourse Analysis Of The Bombing Attack News: An Analysis of Tuen A. van Dijk'S Model. Advances in Social Science Education and Humanities Research Journal Vol 165

9. Ononye, C. F. Lexico-stylistic choices and media ideology in newspaper reports on niger delta conflicts. Indonesian Journal of Applied Linguistics, 7(1), 167-175.

10. Timuçin, M. (2010). Different language styles in newspapers: An investigative framework. Dil ve Dilbilimi Çallşmaları Dergisi, 6(2).

11. Halliday, M.A.K. (1985). An Introduction to Functional Grammar. London: Edward Arnold. 